Izabela Kolodziejczyk-Olczak

Katedra Pracy i Polityki Społecznej

Uniwersytet Łódzki

olczak@uni.lodz.pl

\title{
ZARZĄDZANIE WIEKIEM \\ A POLITYKA WSPIERANIA STARSZYCH \\ PRACOWNIKÓW. DOŚWIADCZENIA POLSKIE NA TLE INNYCH KRAJÓW
}

\section{WPROWADZENIE}

Zjawisko starzenia się ludności jest procesem obiektywnym, nieuniknionym i nieodwracalnym w krótkim czasie. Obok globalizacji, umiędzynarodowienia, pobudzania innowacyjności oraz dynamicznego rozwoju gospodarki opartej na wiedzy postrzega się je jako ważny, współczesny trend społeczno-ekonomiczny. Starzenie się dotyka w szczególności kraje wysoko rozwinięte, wśród których znajduje się także Polska. Najczęściej starzenie się ludności i jego konsekwencje są rozpatrywane na poziomie makro i mezo. Analizy w ujęciu mikro, w szczególności na poziomie przedsiębiorstwa, mają znacznie krótszą historię. Tymczasem następstwa tego procesu odczuwa coraz więcej polskich firm. Starzeją się bowiem konsumenci, interesariusze, a przede wszystkim pracownicy. Organizacje mogą napotkać problemy z pozyskaniem kandydatów do pracy o odpowiednich kompetencjach i w niezbędnej do realizacji celów strategicznych liczbie. Mogą pojawić się kłopoty z utratą jawnej i cichej wiedzy organizacyjnej, przekazywaniem stanowisk w ramach sukcesji czy niedostosowaniem oferty do zmieniających się potrzeb obecnych i potencjalnych klientów. Dlatego konieczne jest podejmowanie działań, których celem jest łagodzenie negatywnych konsekwencji starzenia się zasobów pracy. Jednym z możliwych rozwiązań jest zarządzanie wiekiem $\mathrm{w}$ organizacji. Podejmowane $\mathrm{w}$ tym zakresie przedsięwzięcia wpisują się w koncepcję aktywnego starzenia się. W związku z tym jako cel niniejszej pracy przyjęto wskazanie działań, prowadzących do złagodzenia skutków starzeniem się ludności w skali przedsiębiorstwa. W tym kontekście zarządzanie wiekiem w polskich organizacjach przedstawiono jako przykład holistycznych i systematycznych działan. 


\section{IDEA AKTYWNEGO STARZENIA SIĘ}

Definicja aktywnego starzenia się proponowana przez Światową Organizację Zdrowia (WHO) zawiera trzy filary: zdrowie, włączenie i bezpieczeństwo. Badacze Unii Europejskiej i Banku Światowego koncentrują się przede wszystkim na aktywności na rynku pracy osób w starszym wieku (Hamblin, 2013, s.1). Idea aktywnego starzenia się coraz wyraźniej jest traktowana jako warunek podwyższenia aktywności tej populacji. Dzieje się to zarówno na poziomie Unii Europejskiej, jak i na poziomie jej państw członkowskich. Idea ta obecnie została wpisana w projekt polityczny, którego celem jest dążenie za pomocą wszystkich dostępnych środków do osiągnięcia pożądanego stanu, utożsamianego z jak najdłuższym pozostawaniem $\mathrm{w}$ zdrowiu, sprawności, samodzielności z uwzględnieniem samodzielności ekonomicznej, związanej z utrzymywaniem się z własnej pracy (Kryńska, Szukalski (red.), 2013). Aktywne starzenie się koncentruje się na pomocy ludziom w taki sposób, aby pomimo zaawansowanego wieku mogli być odpowiedzialni za swoje życie tak długo, jak to możliwe i posiadali wkład w gospodarkę i życie społeczeństwa ${ }^{1}$. Działania te są podejmowane przede wszystkim w krajach rozwiniętych.

Według P. Szukalskiego w większości państw europejskich termin active ageing nie jest właściwie rozumiany z uwagi na negatywne konotacje czasownika „starzeć się” w ich językach narodowych. W przypadku języka angielskiego to age oznacza przesuwanie się po linii życia, mierzone coraz większą liczbą lat i ma neutralny wydźwięk. W rezultacie często dochodzi do nieporozumień, w wyniku których aktywne starzenie ograniczane jest do aktywności osób starszych ${ }^{2}$. Dlatego w zdecydowanej większości przypadków następuje zawężenie polityki aktywnego starzenia się do fazy życia poprzedzającej o około 15 lat osiągnięcie wieku emerytalnego. Dodatkowo, w skład tej polityki wchodzą głównie rozwiązania odnoszące się do rynku pracy, skoncentrowane przede wszystkim na aspekcie ekonomicznym z marginalizowaniem, a często pomijaniem, innych wymiarów, może z wyjątkiem zdrowia (Szukalski w: Kryńska, Szukalski (red.), 2013).

Tymczasem wdrażanie szerzej rozumianej polityki aktywnego starzenia się wymaga przede wszystkim prowadzenia holistycznych i systematycznych działań.

Holizm działań polega na ujęciu całościowym, uwzględniającym oddziaływanie na wszystkie sfery życia, a nie tylko na te, które warunkują aktywność zawodową. Oprócz kariery zawodowej należałoby rozważać także inne kariery, takie jak:

1 Wzajemna ocena $w$ Polsce. Wskaźnik aktywnego starzenia się i rozszerzenie go na szczebel regionalny, Komisja Europejska, 2014, http://ec.europa.eu/social/main.jsp?catId=89\&langId=pl\&news $\mathrm{Id}=2099$ \& moreDocuments=yes\&tableName=news $($ marzec 2015$)$.

2 Tak się też stało w Polsce, w sytuacji thumaczenia dotyczącego roku 2012 European year of active ageing and solidarity between generations, określanego jako Rok Aktywnego Starzenia się i Solidarności Międzypokoleniowej. 
Zarządzanie wiekiem a polityka wspierania starszych pracowników....

- zdrowotna (stan zdrowia fizycznego i psychicznego, sprawność),

- edukacyjna (możliwość doskonalenia umiejętności i podnoszenia poziomu wiedzy, co przydatne jest na rynku pracy),

- rodzinna (możliwość godzenia pracy zawodowej z życiem rodzinnym).

Praktyki aktywnego starzenia powinny zmierzać do osiągnięcia równowagi powyższych karier i do osiągnięcia ich równomiernego rozwoju z uwagi na ich wzajemny wpływ.

Z kolei, o systematyczności działań przesądza podejście systemowe, wewnętrznie spójne, długofalowe a także bazujące na cyklu życia i ,zarządzaniu przyszłością”. Działania te nie mogą być podejmowane incydentalnie, pod wpływem krótkookresowych trendów ekonomicznych czy nastrojów społecznych. Muszą być posunięciami uwzględniającymi antycypowane przemiany (Kryńska, Szukalski (red.), 2013; Walker i Maltby, 2012, s.120; Goerres, 2009, s.175; Walker, 2002, s.121).

W rozpowszechnianiu idei aktywnego starzenia się bardzo cenne okazało się ustanowienie 2012 roku Europejskim Rokiem Aktywnego Starzenia się i Solidarności Międzypokoleniowej. Ta inicjatywa Unii Europejskiej wyraźnie wpłynęła na politykę społeczną i na zarządzanie wiekiem. W rezultacie aktywności podejmowanych przez rządy państw-członków Unii Europejskiej ukazało się wiele raportów z badań, porównań podsumowań i ekspertyz tematycznych. Zorganizowano wiele konferencji, spotkań i seminariów, w których uczestniczyli różni interesariusze (Kołodziejczyk-Olczak w: Kryńska, Szukalski (red.), 2013).

\section{2. ŚWIATOWE DZIAŁANIA WSPIERAJĄCE AKTYWNE STARZENIE SIĘ}

Idea aktywnego starzenia się nie jest myślą nową. Od momentu powstania podlegała ewolucji wraz z ewolucją sposobów przeciwdziałania niekorzystnym skutkom starzenia się ludności. W tym zakresie na zwrócenie uwagi zasługuje aktywność Organizacji Narodów Zjednoczonych (ONZ), która podejmuje różnorodne inicjatywy już od lat osiemdziesiątych ubiegłego stulecia (schemat 1).

W 1950 roku odbył się Pierwszy Światowy Kongres Starzenia się, w którym uczestniczyli reprezentanci 14 krajów. Kolejne spotkanie w 2009 roku zgromadziło już reprezentantów 91 krajów. Można więc zauważyć wzrost zainteresowania tematyką z upływem czasu. Przyczyniają się do tego działania podejmowane przez ONZ w zakresie inicjowania międzynarodowej debaty, projektowania i wdrażania inicjatyw wspierających aktywne starzenie się oraz wskazywanie korzyści, jakie te działania przynoszą. W ten nurt wpisują się też cele milenijne z 2000 roku, które dotyczyły rozwoju gospodarczego i społecznego oraz zagadnienia eliminacji ubóstwa. Aktualnie agendy ONZ kontynuują podjęte wcześniej aktywności łączące się $\mathrm{z}$ intensywnym starzeniem się ludności. 


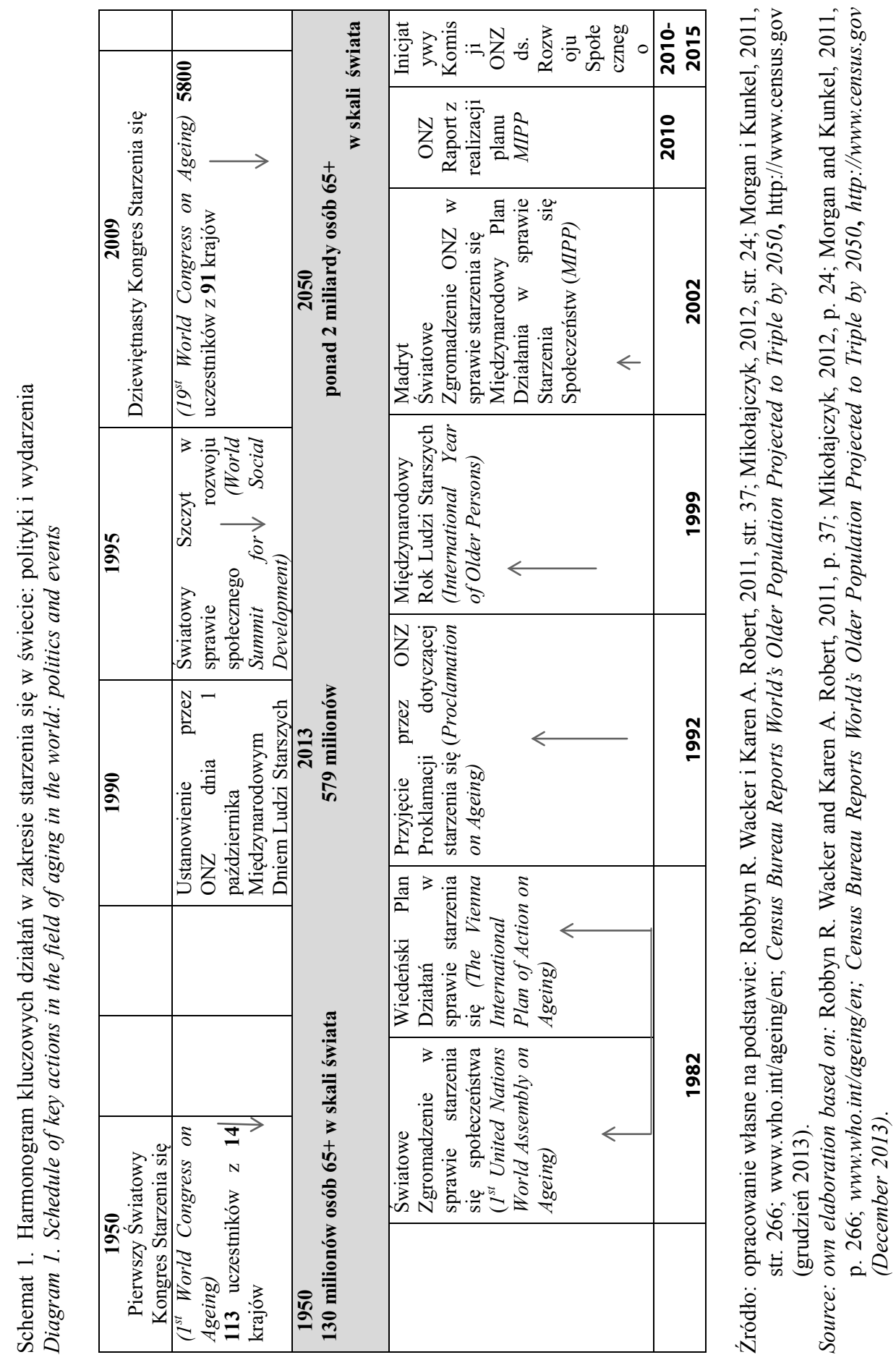


Rozważając przedsięwzięcia na poziomie Unii Europejskiej należy wskazać priorytet inteligentnego rozwoju ${ }^{3}$. Priorytet ów jest realizowany poprzez zachęcanie osób dojrzałych do permanentnego podnoszenia kompetencji na szkoleniach, warsztatach czy uczestnictwie w Uniwersytetach Trzeciego Wieku. W ramy aktywnego starzenia się wpisują się także: tworzenie nowych produktów i usług przyjaznych osobom starszym, kreowanych specjalnie na ich potrzeby związane np. z profilaktyką zdrowego starzenia się, przygotowanie domostw przystosowanych do dhugiego pozostawania samodzielnym, funkcjonowanie i wykorzystywanie innych obszarów gerontechnologii. Promowany przez UE inteligentny rozwój może być realizowany poprzez różnorodne działania mające na celu podnoszenie kompetencji cyfrowych osób dojrzałych.

Zabiegi podejmowane przez UE mogą być pośrednio związane $\mathrm{z}$ aktywnym starzeniem się. Na przykład priorytetem strategii Europa 2020 jest również zrównoważony rozwój ${ }^{4}$. Obecność zagadnienia aktywnego starzenia się w tym priorytecie można dostrzec $\mathrm{w}$ promowaniu sieci i/lub rozwoju przedsiębiorczości firm operujących w ramach silver economy ${ }^{5}$, wdrażaniu inicjatyw podnoszących świadomość dojrzałych konsumentów, tworzenie zrównoważonych czy zielonych miejsc pracy. Rozwiązania ekologiczne, w zakresie ochrony środowiska naturalnego czy nowinki technologiczne zastosowane w energetyce mogą być współtworzone przez międzygeneracyjne zespoły, złożone z młodych i dojrzałych pracowników, dysponujących wiedzą ekspercką i rozległym doświadczeniem.

Bezpośrednio aktywne starzenie się - ograniczone głównie do kariery zawodowej - znaleźć można w trzecim priorytecie strategii Europa 2020, jakim jest rozwój sprzyjający włączeniu społecznemu, który UE zamierza osiągnąć poprzez:

- podniesienie stopy zatrudnienia dzięki tworzeniu większej liczby lepszych miejsc pracy, zwłaszcza dla kobiet, młodych ludzi i starszych pracowników,

- pomaganie młodym ludziom w przewidywaniu zmian i radzeniu sobie z nimi dzięki inwestycjom w podnoszenie kwalifikacji i szkolenia,

- modernizację rynków pracy i systemów opieki społecznej,

- zagwarantowanie, że cała UE odniesie korzyści ze wzrostu6

Obecność zagadnienia aktywnego starzenia się w tym priorytecie można łączyć z następującymi działaniami: wydłużaniem aktywności osób starszych na rynku pracy, promocją przedsiębiorczości osób dojrzałych, rozwojem idei srebrnej gospodarki, włączeniem grup niedostosowanych społecznie i ekonomicznie, wspomaganiem ekonomii społecznej, programów równowaga praca-życie i innych praktyk zarządzania wiekiem oraz tworzeniem dobrobytu osób dojrzałych.

3 http://ec.europa.eu/europe2020/index_pl.htm (marzec 2014).

4 http://ec.europa.eu/europe2020/index_pl.htm (marzec 2014).

5 Przez silver economy, czyli srebrną gospodarkę rozumie się systemy ekonomiczne ukierunkowane na wykorzystywanie potencjału osób starszych - pracowników, pracodawców, klientów, wolontariuszy.

6 http://ec.europa.eu/europe2020/index_pl.htm (marzec 2014). 
Strategia Europa 2020 i jej dokumenty implementacyjne przyczyniają się nie tylko do promocji idei aktywnego starzenia się, ale także do stopniowego wdrażania sugerowanych rozwiązań. Dodatkowo stymulują ten proces inicjatywy centralne. Przykładem jest dofinansowanie działań w ramach Europejskiego Funduszu Społecznego (EFS). W latach 2000-2006 państwa członkowskie UE nie zostały zobowiązane do monitorowania liczby starszych wiekiem beneficjentów działań. W latach 2007-2013 już więcej uwagi poświęcono osobom starszym. To nowe podejście znalazło odbicie w rozporządzeniu w sprawie EFS, w którym starsi pracownicy zostali jednoznacznie określeni jako osobna grupa docelowa. Skutkiem było podejmowanie licznych działań mających na celu zwiększanie zdolności przystosowawczych starszych pracowników, ułatwianie im dostępu do zatrudnienia, promowanie aktywnego starzenia się oraz wdrażanie elastycznych form organizacji pracy w celu osiągnięcia założonych wskaźników. Dodatkowo osoby starsze mogą korzystać z inicjatyw na rzecz uczenia się przez całe życie lub uczestnictwa społecznego, głównie adresowanych do osób niepełnosprawnych (Europejski..., 2010).

W konsekwencji tak ustalonych priorytetów na poziomie europejskim i konkretnych dokumentów implementacyjnych w krajach europejskich powstaje szereg różnorodnych programów, projektów i rozwiązań. Rozmaitość stosowanych rozwiązań wynikać może z historii poszczególnych krajów, różnej sytuacji na rynku pracy i odmiennej jego dojrzałości, a także podejścia do zarządzania zasobami ludzkimi, świadomości procesów demograficznych u menedżerów oraz standardów zarządczych występujących w przedsiębiorstwach na poziomie mikroekonomicznym. Jednocześnie będąc pod pośrednim i bezpośrednim wpływem Unii Europejskiej proces ten $\mathrm{z}$ pewnością będzie dalej podlegał upodabnianiu. Dzieje się tak dzięki upowszechnianiu promowanych idei, szerzeniu dobrych praktyk oraz wyników interdyscyplinarnych badań. Przyczyniają się do tego liczne analizy tematyczne wiodących w skali europejskiej instytucji, takich jak:

- European Employment Observatory (EEO) http://www.eu-employment-observatory.net

- European Foundation for the Improvement of Living and Working Conditions (Eurofound) www.eurofound.europa.eu

- AGE Platform, www.age-platform.eu

- European Centre for the Development of Vocational Training (Cedefop). www. cedefop.europa.eu

- European Centre for Social Welfare Policy and Research, www.euro.centre.org Jednocześnie występuje brak jednego podmiotu europejskiego powołanego wyłącznie do zajmowania się aktywnym starzeniem się, tak w Europie, jak i w Polsce. 


\section{WSPARCIE AKTYWNEGO STARZENIA SIE W POLSCE}

W Polsce w ostatnich kilkunastu latach podjęto szereg działań zmierzających do zapobiegania dezintegracji społecznej, promowania idei aktywnego starzenia się i silver economy. Inicjatywy parlamentu i rządu zaowocowały opracowaniem dokumentów strategicznych określających wizję i kierunki rozwoju kraju zarówno w najbliższych latach, jak i w perspektywie długookresowej do 2030 roku. „Strategia Rozwoju Kraju 2020” oraz „Długookresowa Strategia Rozwoju Kraju - Polska 2030" podkreślają konieczność rozwoju opartego na likwidowaniu największych barier rozwojowych, wzrostu opartego na edukacji, cyfryzacji i innowacyjności. Strategie wyznaczają następujące obszary strategiczne: sprawne i efektywne państwo, konkurencyjna gospodarka, spójność społeczna i terytorialna. Obszary te, podobnie jak i cel główny strategii (wzmocnienie i wykorzystanie gospodarczych, społecznych i instytucjonalnych potencjałów zapewniających szybszy i zrównoważony rozwój kraju oraz poprawę jakości życia ludności), silnie związane są z aktywnym starzeniem się.

Omawiane dokumenty wpisują się w akcję zapobiegania dezintegracji społecznej i promowania idei aktywnego starzenia się. Kwestie te, w bardziej szczegółowy sposób, zawarte są w narodowym planie działania (NAP - National Action Plan). W Polsce, tak jak we wszystkich krajach UE, NAP-y mają za zadanie walkę z ubóstwem i wykluczeniem społecznym przy uwzględnieniu różnych rodzajów ryzyka związanych z utrzymaniem na rynku pracy starszych pracowników w zmieniającym się otoczeniu. W celu bardziej intensywnych działań na rzecz starzejących się zasobów ludzkich został opracowany i wdrażany w Polsce rządowy program „Solidarność pokoleń. Działania dla zwiększenia aktywności zawodowej osób w wieku 50+”, przyjęty przez Radę Ministrów 17 października 2008 roku. Program ten obejmuje szerokie spektrum inicjatyw, których celem jest lepsze wykorzystanie zasobów ludzkich w wieku 50 i więcej lat. Zakłada, z jednej strony, działania, które zwiększają zachęty finansowe do zatrudnienia osób w wieku 50+ przez przedsiębiorców, z drugiej zaś działania, które sprzyjają poprawie kwalifikacji, umiejętności i efektywności pracy tych osób. Zwiększenie wskaźnika zatrudnienia wśród osób po 50. roku życia jest niezbędne dla utrzymania wysokiego wzrostu gospodarczego w Polsce w perspektywie kolejnych kilkunastu lat. Część rozwiązań proponowanych w programie jest adresowana także do osób młodszych, po 45. roku życia (Program..., 2008, s. 4).

Celem programu było osiągnięcie w perspektywie do 2020 r. wskaźnika zatrudnienia osób w wieku 55-64 lata na poziomie 50\%, określonego w Strategii Lizbońskiej (Program..., 2008, s. 5). Obecnie w zaktualizowanym programie cel ten utrzymano (Program..., 2014, s. 6). W programie tym następuje odwołanie do idei aktywnego starzenia się w celu 4. Wspieranie idei aktywnego i zdrowego starzenia się. Cel ma być realizowany przy udziale trzech priorytetów: priorytet 4.1. Upowszechnianie idei aktywnego i zdrowego starzenia się, priorytet 4.2. Upowszechnienie profilak- 
tyki zdrowotnej oraz możliwości poprawy kondycji fizycznej i psychicznej osób $\mathrm{w}$ wieku $50+$ oraz priorytet 4.3 . Wspieranie zmian systemowych rozwiązań dotyczących aktywnego i zdrowego starzenia się poprzez współpracę $\mathrm{w}$ tym zakresie (Program...,2014, s. 49 i nn).

W konsekwencji ostatnich działań powstał w Polsce również Rządowy Program na rzecz Aktywności Spolecznej Osób Starszych na lata 2012-2013 (Rządowy..., 2012) oraz będąca jego kontynuacją Dlugofalowa polityka senioralna na lata 2014-2020 (Dlugofalowa... 2014).

Dokumenty polskie, uwzględniając ,wewnętrzne zróżnicowanie populacji osób starszych", promują zarówno działania mające na celu podtrzymanie aktywności osób starszych i zapewnienie ich udziału w życiu społecznym, jak i działania ukierunkowane na osoby o ograniczonej samodzielności. Polityka senioralna odnosi się do osób starszych, choć są one niejednoznacznie zdefiniowanie ${ }^{7}$. Celem głównym programu jest poprawa jakości i poziomu życia osób starszych dla godnego starzenia się poprzez aktywność społeczną (Rządowy..., 2012, s.19-20). Cel ten realizowany jest poprzez kilka celów szczegółowych, takich jak: 1. Zwiększenie różnorodności i poprawa jakości oferty edukacyjnej dla osób starszych, 2. Tworzenie warunków dla integracji wewnątrz i międzypokoleniowej osób starszych przy wykorzystaniu istniejącej infrastruktury społecznej, 3. Rozwój zróżnicowanych form aktywności społecznej, w tym upowszechnianie wolontariatu, partycypacji w procesach decyzyjnych, w życiu społecznym, w tym udział osób starszych w kształtowaniu polityki publicznej, 4. Zwiększenie dostępności, podniesienie jakości usług społecznych oraz wspieranie działań na rzecz samopomocy i samoorganizacji (Rzadowy..., 2012, s.19-20).

Założenia polskiego „manifestu senioralnego” zarysowanego w powyższych dokumentach, opierają się na przesłaniu, że aktywność społeczna osób starszych często skupia się wokół inicjatyw lokalnych. Dlatego istotne jest zwiększanie wymiaru zaangażowania społecznego osób starszych poprzez włączenie w różnorodne formy edukacji oraz współpracy międzypokoleniowej. Ponieważ problemem jest finansowanie działań adresowanych do osób starszych przez samorządy, na przykład aktywności edukacyjno-kulturalnych, w praktyce ich dostępność zależy od oferty generowanej przez lokalne instytucje i organizacje pozarządowe. Dlatego program ten powstał jako wsparcie organizacji, instytucji działających na rzecz osób starszych. Współpraca międzysektorowa na poziomie lokalnym może istotnie zwiększyć efektywność podejmowanych działań na rzecz aktywności społecznej osób starszych, definiowanych jako osobę w wieku powyżej 60. roku życia.

Podsumowując powyższe wątki, aktywność Polski w kontekście kluczowych inicjatyw Unii Europejskiej przedstawiono na schemacie 2.

7 W przypadku polityki senioralnej nie jest dokładnie sprecyzowany jej beneficjent. Do jej odbiorców włącza się: 1) osoby powyżej pewnego wieku (najczęściej 60 lat), 2) osoby w wieku przedemerytalnym (z reguły mające do momentu uzyskania uprawnień emerytalnych 10-15 lat) i 3) osoby zbliżające się do starości, myślące o własnej starości. 
Zarządzanie wiekiem a polityka wspierania starszych pracowników....

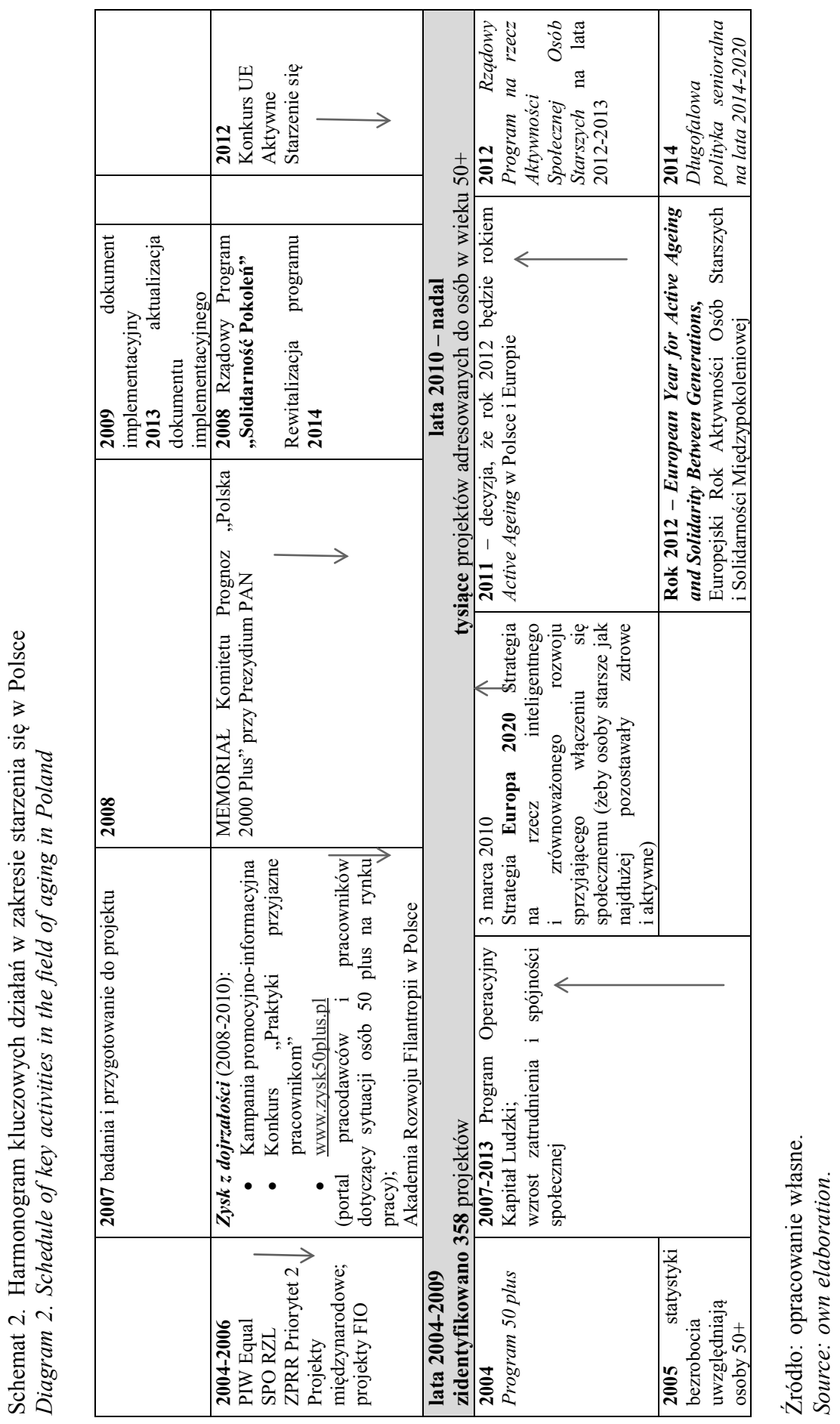


Zarysowane inicjatywy na poziomie europejskim i na szczeblu krajowym zaowocowały pojawieniem się $\mathrm{w}$ poprzedniej perspektywie finansowania (w latach 2004-2009) setek polskich projektów, w których grupą docelową były osoby dojrzałe $^{8}$. Uwzględnienie tej kategorii beneficjentów jako grupy objętej szczególnym wsparciem przyczyniło się do zwiększenia zainteresowania tematyką, mierzonego liczbą realizowanych projektów.

\section{WSPARCIE AKTYWNEGO STARZENIA SIĘ POPRZEZ ODDZIAŁYWANIE NA FIRMY - PRZYKŁADY POLSKICH PROJEKTÓW}

Wśród projektów adresowanych do osób dojrzałych oraz podmiotów wspierających tę grupę, takich jak instytucje rynku pracy, pomocy społecznej, związki zawodowe, organizacje pracodawców czy trzeci sektor znajdują się również projekty skierowane do firm. Pośród projektów systemowych, będących następstwem wdrażania w Polsce opisywanego wcześniej programu „Solidarność pokoleń. Działania dla zwiększenia aktywności zawodowej osób w wieku 50+" można wymienić dwa, skoncentrowane na wsparciu firm i zatrudnionych w nich dojrzałych pracowników.

Projektem przeznaczonym do realizacji w latach 2009-2013, mającym duży dorobek teoretyczny i utylitarny jest projekt „Z wiekiem na plus. Szkolenia dla przedsiębiorstw". Realizatorem był Ośrodek Badań Rynku Pracy na Wydziale Nauk Ekonomicznych Uniwersytetu Warszawskiego w partnerstwie z Polską Agencją Rozwoju Przedsiębiorczości. Był on dofinansowany ze środków Europejskiego Funduszu Społecznego. Celem projektu było podniesienie wśród właścicieli i kadry zarządzającej przedsiębiorstw świadomości i wiedzy w zakresie korzyści płynących z utrzymywania w zatrudnieniu osób w wieku 45/50+ oraz wdrożenie modelowych systemów zarządzania wiekiem w firmach uczestniczących w projekcie ${ }^{9}$.

Drugim, ważnym projektem jest „Wyrównywanie szans na rynku pracy dla osób 50+", realizowany przez Centrum Rozwoju Zasobów Ludzkich w partnerstwie z Uniwersytetem Łódzkim ${ }^{10}$. Głównym celem tego projektu jest promocja aktywności zawodowej kobiet i mężczyzn w wieku 50+ oraz promocja działań na rzecz wydłużenia aktywności zawodowej osób w tym wieku. Założone cele realizuje się przez kompleksowe działania, które w latach 2010-2015 obejmują:

${ }^{8}$ Przedział czasowy wynika z zastosowanej metodologii projektu „Wyrównywanie szans na rynku pracy dla osób 50+", projekty scharakteryzowane zostały w: B. Urbaniak, J. Wiktorowicz (red.), Raport $z$ analizy programów skierowanych do osób 50+ zrealizowanych $w$ Polsce $w$ latach 2004-2009, UŁ, Łódź 2011.

${ }^{9}$ www.45naplus.pl (wrzesień 2013)

${ }^{10}$ Autorka artykułu w okresie od lutego 2010 do grudnia 2013 pełniła funkcję kierownika ds. koordynacji działań UŁ. 
Zarządzanie wiekiem a polityka wspierania starszych pracowników...

- przeprowadzenie szeroko zakrojonych prac badawczych i upowszechnianie ich wyników;

- prace krajowej Sieci Tematycznej pod nazwą „Rada 50+”, w ramach której utworzonych zostało 5 Tematycznych Grup Roboczych;

- ogólnopolską kampanię informacyjno-promocyjną dotyczącą aktywności zawodowej kobiet i mężczyzn w wieku 50+, przewidującą szeroko zakrojone działania, $\mathrm{w}$ tym: stworzenie wielofunkcyjnego portalu $\mathrm{z}$ wydzielonym modułem edukacyjnym, medialną kampanię informacyjno-promocyjną, opracowanie broszury informacyjnej dla osób 50+, organizację 18 konferencji promujących aktywność zawodową kobiet i mężczyzn w wieku 50+;

- przeprowadzenie, metodą blended learning (zajęcia stacjonarne, uzupełnione e-learningiem), szkoleń dla 630 pracowników instytucji rynku pracy i pomocy społecznej;

- opracowanie podręcznika skierowanego do instytucji rynku pracy oraz jednostek organizacyjnych pomocy społecznej, zawierającego rekomendacje w zakresie aktywizacji osób w wieku 50+,

- opracowanie Katalogu Rekomendacji zawierającego propozycje zmian systemowych sprzyjających aktywizacji zawodowej osób w wieku 50+.

Z kolei spośród projektów niesystemowych, na zwrócenie uwagi zasługuje pionierski projekt „Zysk z dojrzałości”, realizowany od 2008 roku przez Akademię Rozwoju Filantropii w Polsce. „Projekt oraz serwis www.zysk50plus.pl jest inicjatywą skierowaną do pracodawców, specjalistów HR oraz instytucji rynku pracy zarówno publicznych, jak i prywatnych. Naszym celem jest promocja i zapewnienie informacji na temat rozwiązań z zakresu zarządzania wiekiem, służących dłuższej i pełniejszej aktywności zawodowej osób powyżej 50. roku życia”. Oprócz kampanii medialnych, prowadzenia strony internetowej, organizowane są także szkolenia, seminaria, konsultacje i konkursy. Akademia Rozwoju Filantropii w Polsce podejmowała też szereg innych inicjatyw mających na celu, m.in.: pomoc osobom starszym w podnoszeniu kwalifikacji (Akademia e-Seniora UPC), przeciwdziałanie dyskryminacji osób starszych (STOP dyskryminacji ze względu na wiek), budzenie w nich potrzeby społecznego zaangażowania (Same plusy. Wolontariat 50+) czy budowanie więzi z młodym pokoleniem (Laczymy pokolenia!). Portal gromadzi dobre praktyki polskie i zagraniczne, udziela rad i wsparcia pracownikom w starszym wieku oraz organizacjom pragnącym zmierzyć „,zysk z dojrzałości”, co można rozumieć w kontekście monitorowania efektów wprowadzonych ulepszeń i zastosowania narzędzi zarządzania wiekiem. Portal otwiera także przestrzeń do nawiązywania kontaktów.

Zestawienie powyższe, oczywiście, nie wyczerpuje listy kluczowych projektów, lecz jedynie wskazuje te najbardziej zbliżone tematycznie do zarządzania wiekiem. 


\section{ZARZĄDZANIE WIEKIEM JAKO ODPOWIEDŹ NA STARZENIE SIĘ LUDNOŚCI}

Zdrowi i kompetentni pracownicy osiągają lepsze wyniki w pracy i mogą podnosić swoją jakość życia. Zatrudniające ich organizacje, dzięki wyższej wydajności pracowników, mogą poszczycić się lepszą produktywnością i wizerunkiem w otoczeniu, które poprawiają jej konkurencyjność. Dla osiągnięcia tego stanu wprowadzono między innymi ideę zarządzania wiekiem.

W węższym ujęciu zarządzanie wiekiem jest przyporządkowywane do zarządzania zasobami ludzkimi (Jaros, Krajewski, Mackiewicz, 2010: 50; Urbaniak, Wieczorek, 2007: 11, Liwiński, Sztanderska, 2010; Schimanek, 2010: 48). Termin „zarządzanie wiekiem" może odnosić się do różnych wymiarów zarządzania zasobami ludzkimi w ramach organizacji z wyraźnym naciskiem na starzenie się (Walker, 2007), ale także można traktować je szerzej. W takim ujęciu zarzadzanie wiekiem nawiązuje do polityki lub rokowań zbiorowych (Walker, 2005, s. 685). Termin zarządzanie wiekiem łączony bywa z zarządzaniem różnorodnością: „(...) to „element zarządzania zasobami ludzkimi, a dokładniej: element zarządzania różnorodnością. Polega ono na realizacji różnorodnych działań, które pozwalają na bardziej racjonalne i efektywne wykorzystanie zasobów ludzkich w przedsiębiorstwach dzięki uwzględnianiu potrzeb i możliwości pracowników w różnym wieku" (Liwiński, Sztanderska, 2010: 3). Generalnie, instrumenty zarządzania wiekiem mają na celu usuwanie barier związanych $\mathrm{z}$ wiekiem i/lub promują różnorodność ze względu na wiek, pomagają stworzyć środowisko, w którym poszczególni pracownicy są w stanie wykorzystać swój potencjał, nie będąc w gorszej sytuacji ze względu na wiek (Naegele, Walker, 2006: 3).

Zarządzanie wiekiem jest nowym zagadnieniem, które w literaturze zagranicznej pojawiło się niecałe dwadzieścia lat temu, a w polskiej funkcjonuje od kilku lat (Kołodziejczyk-Olczak, 2014). W szerszym ujęciu zarządzanie wiekiem można rozpatrywać na trzech poziomach: jednostki, przedsiębiorstwa i społeczeństwa (tablica 1). Na każdym z poziomów zarządzania wiekiem rodzą się różnorodne możliwości. Zarządzanie wiekiem jest zawsze przedstawione jako sposób podejścia, stanowisko lub planowane działanie prowadzące do eliminowania zarysowanych problemów. W rezultacie zarządzania wiekiem na wszystkich poziomach tworzą się wiązki korzystnych efektów. Przedstawiono je w tablicy 1 zgodnie z koncepcją J. Ilmarinena. Jako przykład można wskazać następujące efekty stosowania zarządzania wiekiem na poziomie społeczeństwa: mniejsza dyskryminacja ze względu na wiek, późniejsze przejście na emeryturę, mniejsze koszty bezrobocia, mniejsze koszty opieki zdrowotnej, wzmocnienie gospodarki narodowej, lepsza opieka społeczna. 
Tablica 1. Poziomy zarządzania wiekiem

Table 1. Levels of age management

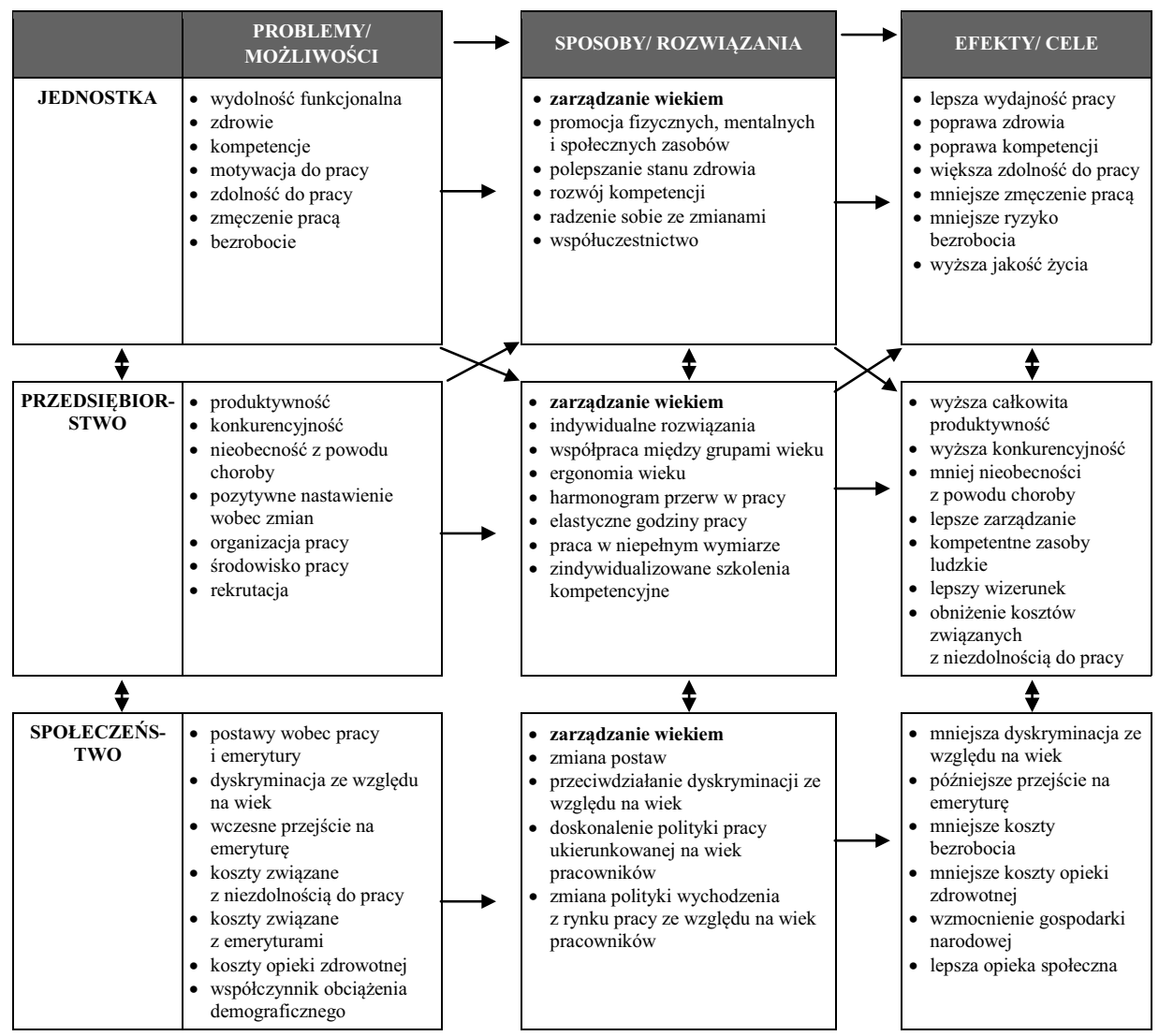

Źródło: opracowanie własne na podstawie Ilmarinen, 2010.

Source: own elaboration based on Ilmarinen, 2010.

J. Ilmarinen ujmuje chronologicznie etapy rozwoju koncepcji zarządzania wiekiem jako: czas badań, konceptualizacji i szkoleń (w latach 1990-1999) i trwającą w latach 2000-2009 fazę tworzenia studiów przypadków, poszukiwania dobrych praktyk oraz typologizacji (Ilmarinen, 2010). W latach 2009-2015 można mówić o kontynuacji badań, ze znacznym ich nasileniem w 2012 roku, który był Europejskim Rokiem Aktywnego Starzenia się i Solidarności Międzypokoleniowej (tłumaczenie Autorki).

Zarządzanie wiekiem odnoszone do poziomu przedsiębiorstwa jest sposobem zarządzania zasobami ludzkimi z uwzględnieniem starzenia się tychże zasobów. Obejmuje ono różnorakie, dostosowane do dojrzałych pracowników, działania związane z organizacją pracy, zatrudnieniem, rekrutacją, szkoleniami, zarządza- 
niem wiedzą, tworzeniem programów równoważących pracę z życiem prywatnym, kreowaniem zrównoważonych miejsc pracy.

Badania polskich przedsiębiorstw wskazują, że w zależności od typu strategii zarządzania wiekiem przyjmowanej przez organizacje, dominują konkretne praktyki zarządzania wiekiem i narzędzia wdrożone w ich ramach. Polskie organizacje $\left(\mathrm{N}=928^{11}\right)$ przyjmowały strategie reaktywne $-\mathrm{w}$ reakcji na zaistniałe zmiany w otoczeniu - bądź proaktywne jako odpowiedź na zmiany przewidywane (Kołodziejczyk-Olczak, 2014). Poszczególnym typom strategii odpowiadały instrumenty i praktyki, których zasięg był operacyjny lub strategiczny (tablica 2).

Przyjęcie strategii reaktywnych („,skąpe zasoby”, „obniżanie wymagań pracy”) powoduje, że firmy sięgają po dojrzałych pracowników w reakcji na pojawiający się brak wykwalifikowanych pracowników, dostrzegając konieczność dostosowania fizycznych warunków pracy. Strategie, które można określić mianem twardych, koncentrują się na ekonomicznych korzyściach i motywach, a pracodawcy zdają się postrzegać efekty ich wdrażania w krótkiej (operacyjnej) perspektywie. Są one pochodną bieżącej sytuacji, deficytu zasobów ludzkich w aspekcie ilości i jakości (kompetencji). Strategie proaktywne ${ }^{12}$ - miękkie - opierają się na innej filozofii. Liczą się społeczne aspekty zarządzania, a ujawniane korzyści dają obraz firmy różnorodnej, elastycznej, wsłuchanej w potrzeby różnych interesariuszy otoczenia, zwracającej uwagę na motywy ważne dla wszystkich. Takie zarządzanie wiekiem uwzględnia dłuższą perspektywę i możliwości odnoszenia korzyści odroczonych, natomiast podejście twarde związane jest raczej z efektami krótkookresowymi.

Podobne pytanie stawiają sobie inni badacze $\mathrm{w}$ ramach projektu ASPA (Activating Senior Potential in Ageing Europe): Czy starzenie się ludności na bezprecedensową skalę spowoduje, że pracodawcy przyjmą aktywną postawę, wdrożą polityki, w których płaca i wydajność są powiązane a młodsi i starsi pracownicy są traktowani jednakowo. W konsekwencji może się okazać, że nie tylko potrzeba jest matką wynalazków, ale również matką zmiany nawyków w polityce kadrowej (van Dalen, Henkens, Schippers, 2010, ss.1015-1036).

${ }^{11}$ Badania przeprowadzone zostały na reprezentatywnej próbie 928 pracodawców polskich.

12 „Wzmacniania zasobów”, „nauki międzypokoleniowej” i „,cyklu życia”. Nazewnictwo strategii zostało zaczerpnięte z Wallin, Hussi. Sposób realizacji strategii zarządzania wiekiem przez polskie organizacje został zbadany za pomocą autorskich wskaźników cząstkowych oraz wskaźnika syntetycznego. Więcej: Kołodziejczyk-Olczak I., Zarzadzanie pracownikami w dojrzałym wieku. Wyzwania i problemy, Wydawnictwo Uniwersytetu Łódzkiego, Łódź 2014. 
Zarządzanie wiekiem a polityka wspierania starszych pracowników...

Tablica 2. Strategie zarządzania wiekiem wraz z praktykami i instrumentami

Table 2. Age management strategies, practices and instruments

\begin{tabular}{|c|c|c|c|}
\hline \multirow{2}{*}{$\begin{array}{l}\text { Typologia strategii } \\
\text { Wallin, Hussiego }\end{array}$} & \multicolumn{3}{|c|}{ Strategie zarządzania wiekiem w Polsce } \\
\hline & praktyki & instrumenty & zasięg \\
\hline $\begin{array}{l}\text { STRATEGIA REAKTYWNA } \\
\text { "SKĄPE ZASOBY” }\end{array}$ & & Dostosowanie stanowisk & \\
\hline $\begin{array}{l}\text { STRATEGIA REAKTYWNA } \\
\text { „OBNIŻANIE WYMAGAŃ } \\
\text { PRACY” }\end{array}$ & $\begin{array}{l}\text { Pracownicy to } \\
\text { ręce do pracy. } \\
\text { Rekrutacja. } \\
\text { Organizacja pracy. } \\
\text { Ergonomia. } \\
\text { Stereotypowe } \\
\text { postrzeganie } \\
\text { pracowników. }\end{array}$ & $\begin{array}{l}\text { pracowników 50+. } \\
\text { Ergonomiczne stanowiska pracy. } \\
\text { Zatrudnienie w niepełnym } \\
\text { wymiarze, telepraca, job } \\
\text { sharing, praca tymczasowa, } \\
\text { samozatrudnienie. } \\
\text { Rekrutacja bez dyskryminacji ze } \\
\text { względu na wiek. } \\
\text { Rekrutacja emerytowanych } \\
\text { pracowników. } \\
\text { Elastyczne przejście na emeryturę } \\
\text { pracowników starszych. }\end{array}$ & Operacyjny \\
\hline $\begin{array}{l}\text { STRATEGIA } \\
\text { PROAKTYWNA I STOPNIA } \\
\text { „WZMACNIANIE } \\
\text { ZASOBÓW” } \\
\end{array}$ & & $\begin{array}{c}\text { Wynagradzanie za kompetencje. } \\
\text { Kafeteryjne wynagradzanie } \\
\text { Badanie opinii starszych } \\
\text { pracowników. }\end{array}$ & \\
\hline $\begin{array}{l}\text { STRATEGIA } \\
\text { PROAKTYWNA } \\
\text { II STOPNIA } \\
\text { „NAUKA } \\
\text { MIEDZYPOKOLENIOWA” }\end{array}$ & $\begin{array}{l}\text { Zarząadzanie } \\
\text { wiedza. }\end{array}$ & $\begin{array}{c}\text { Dobór narzędzi motywacyjnych } \\
\text { do wartości i oczekiwań } \\
\text { pracowników dojrzałych. } \\
\text { Międzygeneracyjne zespoły } \\
\text { pracownicze. }\end{array}$ & \\
\hline $\begin{array}{l}\text { STRATEGIA } \\
\text { PROAKTYWNA } \\
\text { III STOPNIA } \\
\text { „PODEJŚCIE CYKLU } \\
\text { ŻYCIA” }\end{array}$ & $\begin{array}{c}\text { Dobrostan } \\
\text { pracowniczy. } \\
\text { Work-Life } \\
\text { Balance. } \\
\text { Podmiotowość } \\
\text { pracowników. } \\
\text { Motywowanie. } \\
\text { Różnorodność. } \\
\text { Osobiste zasoby. } \\
\text { Zrównoważone } \\
\text { miejsca pracy. }\end{array}$ & $\begin{array}{c}\text { Metody szkoleń dostosowane } \\
\text { do potrzeb i możliwości osób } \\
\text { starszych. } \\
\text { Starsi pracownicy jako coache } \\
\text { i mentorzy. } \\
\text { Procedury zachowania } \\
\text { i przekazywania wiedzy cichej } \\
\text { i jawnej. } \\
\text { Praca zadaniowa. } \\
\text { Profilaktyka i ochrona zdrowia, } \\
\text { pobyty sanatoryjne i w ośrodkach } \\
\text { spa, programy wellness, treningi, } \\
\text { akcje sportowe. } \\
\text { Akcje budujące wizerunek } \\
\text { pracodawcy z wyboru. } \\
\text { Outplacement. } \\
\text { Wolontariat pracowniczy. } \\
\text { AC/DC/ocena } 360^{\circ}\end{array}$ & Strategiczny \\
\hline
\end{tabular}

Źródło: opracowanie własne na podstawie Kołodziejczyk-Olczak, 2014.

Source: own elaboration based on Kolodziejczyk-Olczak, 2014. 
Inni badacze podkreślają ponadto, że zasady zarządzania wiekiem na poziomie przedsiębiorstwa pozostają zwykle pod wpływem jego kultury organizacyjnej, ale także konieczności dostosowania się organizacji do zmian koniunktury, wynikających z recesji gospodarki (van Stolk, 2013). Wartości, normy, przekonania i założenia interesariuszy zarządzania, a w szczególności kadry zarządzającej, pracowników i związków zawodowych wpływają na styl prowadzenia zarządzania wiekiem. Zarazem stan gospodarki może sytuacyjnie wpływać na projektowanie, monitorowanie i wszelkie zmiany instrumentów zarządzania wiekiem.

Na politykę zarządzania wiekiem na poziomie przedsiębiorstwa wpływa także polityka społeczna i zakres polityki senioralnej w danym kraju oraz jej zakorzenienie, długość i powszechność stosowania rozmaitych instrumentów. $Z$ umieszczonych wcześniej schematów 1 i 2 wyraźnie widać przesunięcie w czasie działań polskich w stosunku do poczynań światowych i europejskich. Opóźnienie sięga kilku dekad. Prawdopodobnie wraz $\mathrm{z}$ nasileniem się zmian demograficznych przedsiębiorstwa polskie zaczną coraz częściej sięgać po starszych pracowników, zaś wdrażanie zarządzania wiekiem w polskich przedsiębiorstwach się upowszechni (Woszczyk, 2011, s. 158). Może się to też stać w momencie uświadomienia sobie wieloaspektowych korzyści płynących z zarządzania wiekiem, któremu często towarzyszy kreowanie innowacyjnej, bezpiecznej, etycznej i zrównoważonej organizacji.

Inne badania polskich pracodawców pokazują, że w firmach nadal stosunkowo rzadko spotykane jest zarządzanie wiekiem i długofalowe planowanie kariery zawodowej uwzględniające spersonalizowane plany szkoleniowe i systematyczną ocenę kompetencji, ale też wiedza na temat zarządzania wiekiem jest niewielka. Stosunkowo niewiele polskich firm stosuje rozwiązania, które ułatwiają pracę osobom w wieku 50+, poprzez dostosowanie metod i technik do zmieniających się wymagań fizycznych, predyspozycji i zdrowia. W małych firmach głównie następuje przesuwanie starszych pracowników na inne stanowiska, a w dużych prowadzi się czasem specjalne programy, oparte zwykle na mentoringu (Solidarność..., 2014).

Wśród polskich przedsiębiorców występuje „kosztowe” postrzeganie pracowników w wieku 50+ jako mniej produktywnych i „droższych” (Perek-Białas, Turek, 2012). Pracodawcy, myśląc o konsekwencjach starzenia się pracowników dla swoich firm, na pierwszym planie widzą koszty wynikające ze stanu zdrowia (potencjalne zachorowania) starszych pracowników, mimo że pracownicy dojrzali nie nadużywają zwolnień lekarskich (Diagnoza ..., 2013).

Mimo dającego się obserwować postępu, zarządzanie wiekiem pozostaje w polskich organizacjach na niezbyt wysokim poziomie, a wachlarz wdrażanych rozwiązań jest dość wąski.

Chociaż idea aktywnego starzenia się wciąż zyskuje na znaczeniu to aktualna sytuacja Polski w zakresie jej wdrożenia nie jest najlepsza. Według wskaźnika aktywności osób starszych „Active Ageing Index (AAI) 2012”, Polska zajmuje 25 miejsce w rankingu na 27 krajów UE. Gorsza sytuacja występuje jedynie na Litwie i na Malcie. W czołówce znajdują się: Szwecja, Dania, Holandia, Finlandia 
i Wielka Brytania. Cytowany wskaźnik służy do pomiaru nie tylko dobrobytu osób starszych, ale również wkładu, jaki wnoszą w życie społeczeństwa. Ma on złożony charakter, a na cztery uwzględnione w nim zasadnicze aspekty składają się łącznie 22 wskaźniki cząstkowe. Aspektom przypisuje się następujące wagi:

1. Zatrudnienie (poziom zatrudnienia 55-59, 60-64, 65-69, 70-74) - waga 35\%;

2. Uczestnictwo w życiu społeczeństwa (wolontariat, opieka nad dziećmi i wnukami, opieka nad osobami starszymi, aktywność polityczna) - waga 35\%;

3. Niezależne życie w zdrowiu i bezpieczeństwie (ćwiczenia fizyczne, dostęp do opieki zdrowotnej, niezależne życie, bezpieczeństwo finansowe, bezpieczeństwo fizyczne, uczenie się przez całe życie) - waga 10\%;

4. Możliwości i warunki sprzyjające aktywnemu starzeniu się (pozostała oczekiwana długość życia w wieku 55 lat, oczekiwana część życia w zdrowiu w wieku 55 lat, kondycja psychiczna, korzystanie z technologii informacyjno-komunikacyjnych, więzi społeczne, poziom wykształcenia) - waga 20\% (Wzajemna..., s. 2-3). Uwzględniono w nim także podstawowe wymiary aktywnego starzenia, takie jak: aktywność zawodowa, społeczna, opiekuńcza, polityczna, edukacyjna, fizyczna, bezpieczeństwo finansowe, dostęp do usług medycznych, kondycja fizyczn i zdrowotna, czy też korzystanie z nowoczesnych technologii.

\section{PODSUMOWANIE}

Niska lokata Polski w opisanym powyżej rankingu wynika z pewnością w dużej mierze z faktu, że obecnie na tle Europy poziom aktywności zawodowej osób, które ukończyły już 50 lat, jest w Polsce bardzo niski. Pracownicy dość wcześnie opuszczają rynek pracy. Wyniki badań potwierdzają niską aktywność starszych pokoleń także w innych sferach życia. Biorąc pod uwagę szersze spektrum różnego rodzaju aktywności, np. uczenie się przez całe życie, aktywność społeczną, rekreację, nie ulega wątpliwości, że starsze pokolenia Polaków są na ogół pokoleniami biernymi. Nie przesądza to jednak o tym, że kolejne roczniki będą przyjmowały podobne wzorce (Turek, 2013, s.103). Taki pogląd można sformułować na podstawie postawionej diagnozy i podejmowanych licznych działań na szczeblu ogólnopolskim i na poziomach lokalnych. Przeświadczenie takie wynika także z obserwowanej zmiany pokoleniowej. Tradycjonaliści są zastępowani znacznie bardziej aktywnymi reprezentantami generacji BB oraz X, a także coraz liczniej obecnymi na rynku pacy pokoleniami Y czy Z (Kołodziejczyk-Olczak, 2014a i 2014b).

Rozpowszechnianie się filozofii zarządzania wiekiem i wdrażanie jego instrumentów w polskich przedsiębiorstwach może przyczynić się do rozwoju koncepcji aktywnego starzenia się. Kunisch, Boehm i Boppel jako jeden z warunków zrozumienia aktywnego starzenia się proponują przyjęcie perspektywy interesariuszy organizacji. W budowaniu strategii uwzględnia się bowiem megatrendy otoczenia, ale najbardziej wartościowym podejściem zdaje się zintegrowanie potrzeb zewnętrz- 
nych i wewnętrznych interesariuszy. Autorzy nakreślili w tym zakresie perspektywę ekonomiczną, społeczną, zarządzania zasobami ludzkimi i przywództwa, marketingową i innowacyjności (2011, s. 12-15, part A).

Kontekst zarządzania wiekiem realizowanego w polskich przedsiębiorstwach stanowią uwarunkowania istniejące na poziomie ogólnokrajowym, takie jak: polityka państwa, rozwiązania prawne, rozstrzygnięcia administracyjne. Państwo czyni co prawda starania $\mathrm{w}$ tym zakresie, ale opracowywane i wdrażane instrumenty organizacyjne i finansowe powinny jeszcze bardziej realnie zachęcać firmy do stosowania zarządzania wiekiem. Konieczny jest stały monitoring, intensyfikacja działań, między innymi dobór instrumentów z większym uwzględnieniem wyników badania preferencji i oczekiwań różnorodnych pracodawców. Kafeteria narzędzi powinna umożliwić przedsiębiorstwom bez względu na wielkość, formę własności, lokalizację czy typ działalności, znalezienie dogodnego dla siebie rozwiązania. Niezbędna wydaje się dalsza i bardziej intensywna promocja zarządzania wiekiem oraz idei aktywnego starzenia się w różnorodnych mediach i szeroka publiczna dyskusja na ten temat. Rozległy kontekst tego dialogu stanowi system zabezpieczenia społecznego, niska dzietność społeczeństwa, zmiany funkcjonowania rodzin i stylu życia, kwestie mobilności i migracji różnych grup społecznych, a także zaostrzająca się walka konkurencyjna w globalnym, zinformatyzowanym i wielokulturowym otoczeniu przedsiębiorstw.

\section{LITERATURA}

Dtugofalowa polityka senioralna na lata 2014-2020, Warszawa 2014, www. mpips.gov.pl

Europejski Fundusz Społeczny i starsi pracownicy, Unia Europejska, 2010.

Goerres A., 2009, The Political Participation of Older People in Europe. The Greying of our Democraties, Palgrave Macmillan, NY.

Ilmarinen J., 2010, Sustainable employability and workability, ESF-Age Network, 18-19.10.2010 Maastricht.

Informacja na temat podejmowanych $w$ Polsce działań na rzecz osób starszych - realizacja madryckiego planu działania na rzecz osób starszych, ekspertyza Ministerstwa Pracy i Polityki Społecznej, 2010, www.mpips.pl.

Jaros R., P. Krajewski, M. Mackiewicz (red.), 2010, Osoby po 45. roku życia na rynku pracy Lubelszczyzny. Fundacja CBOS, Warszawa.

Hamblin K.A., 2013, Active ageing in the European Union. Policy Convergence and Divergence, Palgrave Macmillan, NY.

Kołodziejczyk-Olczak I., 2014, Zarządzanie pracownikami w dojrzatym wieku. Wyzwania i problemy, Wydawnictwo Uniwersytetu Łódzkiego, Łódź.

Kołodziejczyk-Olczak I., Zaangażowanie pracowników w różnym wieku, Zarządzanie zasobami ludzkimi, nr 2/2014a.

Kołodziejczyk-Olczak I., Praktyki zarządzania międzygeneracyjnego $w$ obszarze rekrutacji $i$ selekcji pracowników, Zarządzanie Zasobami Ludzkimi, nr 5/2014b.

Kołodziejczyk-Olczak I., 2013, Zarządzanie wiekiem - jak pracodawcy moga odpowiadać na wyzwania demograficzne? [w:] E. Kryńska, P. Szukalski (red.), Rozwiąania sprzyjające aktywnemu starzeniu się w wybranych krajach Unii Europejskiej, Uniwersytet Łódzki, Łódź. 
Kryńska E., Krzyszkowski J., Urbaniak B., Wiktorowicz J. (red.), 2013, Diagnoza obecnej sytuacji kobiet i mężczyzn 50+ na rynku pracy w Polsce, Uniwersytet Łódzki, Łódź.

Kryńska E., Szukalski P. (red.), 2013, Rozwiazania sprzyjające aktywnemu starzeniu się w wybranych krajach Unii Europejskiej, Uniwersytet Łódzki, Łódź.

Kunisch S., Boehm S., Boppel M. (eds.), 2011, From Grey to Silver. Managing the Demographic Change Successfully, Springer.

Liwiński J., Sztanderska U., Wstępne standardy zarządzania wiekiem $w$ przedsiębiorstwach, PARP, Warszawa 2010.

Mikołajczyk B., Międzynarodowa ochrona praw osób starszych, Wolters Kluwer Polska, Warszawa 2012.

Morgan L.A., S.R. Kunkel, 2011, Ageing, Society, and the Life Course, Springer, New York.

Naegele G., Walker A., A guide to good practice in age management, Office for Official Publications of the European Communities, 2006.

Perek-Białas J., Turek K., 2012, Organisation-level policy toward older workers in Poland, International Journal of Social Welfare vol. 21.

Polska 2030. Trzecia fala nowoczesności. Dlugookresowa Strategia Rozwoju Kraju, Warszawa 2013.

Program Solidarność pokoleń. Działania dla zwiększenia aktywności zawodowej osób w wieku 50+, Warszawa 2008.

http://analizy.mpips.gov.pl/images/stories/publ_i_raporty/Program50+.pdf.

Program Solidarność pokoleń. Działania dla zwiększenia aktywności zawodowej osób w wieku 50+, Warszawa 2014 MONITOR POLSKI DZIENNIK URZĘDOWY RZECZYPOSPOLITEJ POLSKIEJ, Warszawa, dnia 4 lutego $2014 \mathrm{r}$.

Robbyn R. Wacker, Karen A. Robert, 2011, Aging Social Policies: An International Perspective, Sage Publications, London.

Rządowy Program na rzecz Aktywności Społecznej Osób Starszych na lata 2012-2013, Warszawa 2012, Załącznik do uchwały nr 137 Rady Ministrów z dnia 24 sierpnia 2012 r.

Schimanek T., 2010, Co to jest zarządzanie wiekiem? [w:] Aktywizacja zawodowa osób 50+ i zarzadzanie wiekiem. Informacje użyteczne dla instytucji rynku pracy, Akademia Rozwoju Filantropii w Polsce, Warszawa.

Szukalski P., 2013, Wstęp, [w:] E. Kryńska, P. Szukalski (red.), Rozwiazania sprzyjajace aktywnemu starzeniu się w wybranych krajach Unii Europejskiej, Uniwersytet Łódzki, Łódź.

Turek K., 2013, Starzenie się ludności jako wyzwanie dla gospodarki, rynku pracy, polityki i obywateli w J. Górniak (red.), Młodość czy doświadczenie? Kapitał ludzki w Polsce Raport podsumowujący III edycję badań BKL z 2012 roku, PARP, Warszawa.

Urbaniak B., I. Wieczorek, 2007, Zarzqdzanie wiekiem [w:] B. Urbaniak (red.), Pracownicy 45+ $w$ naszej firmie, UNDP, Warszawa.

van Stolk Ch., 2013, Impact of the recession on age management policies, European Foundation for the Improvement of Living and Working Conditions, Dublin.

van Dalen H. P., Henkens K., Schippers J., 2010, How do employers cope with an ageing workforce? Views from employers and employees, Demographic Research: vol.22, art. 32.

Wallin, M., Hussi, T., 2011, Best practices in Age Management - evaluation of organisation cases. Final report. Finnish Work Environment Fund.

Walker A., 1997, Combating Age Barriers in Employment-A European Research Report, European Foundation, Dublin.

Walker A., 2002, Strategy for Active Ageing, International Social Security Rewiev, vol. 55.

Walker A., 2005, The Energence of Age Management in Europe, International Journal of Organisational Behaviour, vol. 10 (1).

Walker A, Maltby T., 2012, Active ageing: A strategic policy solution to demographic ageing in the European Union, INTERNATIONAL JOURNAL OF SOCIAL WELFARE, 21.

Woszczyk P. (red.), 2011, Zarzq̨dzanie pracownikami 50+. Teoria a praktyka, HRP, Łódź. 
Wzajemna ocena w Polsce. Wskaźnik aktywnego starzenia się i rozszerzenie go na szczebel regionalny, Komisja Europejska, 2014 http://ec.europa.eu/social/main.jsp?catId=89\&langId=pl\&newsId=2099\& moreDocuments=yes\&tableName=news (marzec 2015).

Strony internetowe:

http://www.un.org (marzec 2013)

http://ec.europa.eu/europe2020/index_pl.htm (marzec 2013)

www.45naplus.pl (styczeń 2014)

www.zysk50plus.pl (styczeń 2014)

www.who.int/ageing/en (luty 2014)

http://www.census.gov Census Bureau Reports World's Older Population Projected to Triple by 2050

(kwiecień 2014).

\title{
AGE MANAGEMENT AND OLDER WORKERS SUPPORT POLICIES IN POLAND AND OTHER COUNTRIES.
}

\begin{abstract}
Population ageing is one of the most important demographic trends in modern societies. The process has broad implications in both macro- and micro-scale. In the article we focus on ageing-related challenges for enterprises. This area is very important for contemporary and future economies. Customers, employees and stakeholders of companies are getting older. In this changing environment new challenges appear including problems in hiring employees with relevant competencies, loosing organizational knowledge, employee succession, or mismatch between offered goods and market needs of changing costumers. Therefore, it becomes necessary to implement Age Management (AM) in organizations. The activities of employers in this area have to be supported by economic and legal instruments, and actions towards an increase of awareness and sensitivity to age-related issues.
\end{abstract}

Keywords: Age Management, older worker, active ageing 